\title{
In Deep Water: Towards a Greater Commitment for Human Rights in Sea Operations Coordinated by FRONTEX?
}

Juan Santos Vara*

Soledad R. Sánchez-Tabernero**

Paper prepared for the Biannual Meeting of the European Studies

Association, Boston, MA, March 5th-7th, 2015.

\section{Introduction}

The EU has recently adopted Regulation 656/2014, of 15 May 2014, laying down rules for the surveillance of the external sea borders in the context of operational cooperation coordinated by the European Agency for the Management of Operational Cooperation at the External Borders of the Member States of the European Union (Frontex). ${ }^{1}$ In spite of the pressing need for a common legal framework for the deployment of sea operations coordinated by Frontex, the process leading to the adoption of Regulation 656/2014 has been lengthy and has required the Court of Justice of the EU to give a ruling in Case C-355/10. ${ }^{2}$

One of the main legal problems raised by the implementation of border surveillance operations coordinated by Frontex is that participating Member States interpreted the applicable rules differently both in relation to the detection and interception of vessels as, more importantly, in relation to search and rescue situations.

The present paper has benefited from the support of research project DER2012-36703, financed by the Spanish Ministry of Economy and Competitiveness.

* Professor of Public International and European Law, Director of the Master in European Studies at the University of Salamanca. Contact: savajuan@usal.es.

** Doctoral Research Fellow in Public International and European Law, University of Salamanca. Contact: $\underline{\text { soledadrst@usal.es. }}$

\footnotetext{
${ }^{1}$ Regulation $n^{\circ}$ 656/2014 of the European Parliament and of the Council of 15 May 2014 establishing rules for the surveillance of the external sea borders in the context of operational cooperation coordinated by the European Agency for the Management of Operational Cooperation at the External Borders of the Member States of the European Union, OJ L 189/93, 27.6.2014.

${ }^{2}$ Judgment of 5 September 2012, European Parliament v. Council, C-355/10.
} 
In 2010, the Council adopted Decision 2010/252/EU ('the Decision') with the aim of establishing clear rules of engagement for joint patrolling and for the disembarkation of intercepted or rescued migrants at sea. $^{3}$ The aim was to overcome the different interpretations of international maritime law adopted by Member States and their diverging practices to ensure the efficiency of sea operations coordinated by the Agency. The Decision was adopted as a Council measure implementing the Schengen Borders Code in accordance with the regulatory procedure with scrutiny. However, the European Parliament argued that the Decision introduced new essential elements into the Schengen Borders Code that went beyond the implementing powers conferred under Article 12 (5) of Schengen Borders Code. Consequently, the Parliament brought an action before the Court of Justice of the EU. The Court annulled the Decision because it contained essential elements on the surveillance of the sea external borders of the Member States which should have been adopted by the EU legislature. ${ }^{4}$ However, the Court decided to maintain the effects of the Decision until it was replaced by new rules.

Frontex and the EU Member States have been criticized for not carrying out sea surveillance operations coordinated by the Agency in full compliance with human rights obligations. While Frontex and the Member States are clearly obliged to respect human rights when carrying out maritime surveillance operations within their territorial waters and contiguous zone, the question is much more complex on the high seas and especially in the territorial waters of a third country. Therefore, the most problematic question in Frontex operations is the extraterritorial application of human rights obligations of the EU and its Member States. Furthermore, in the extraterritorial border surveillance operations different legal frameworks converge: namely, the United Nations Convention on the Law of the Sea ('UNCLOS'), the International Convention on Maritime Search and Rescue ('SAR Convention') and the International Convention for the Safety of Life at Sea (SOLAS Convention).

Every year thousands of migrants and asylum seekers attempt to reach the territory of the EU Member States by sea in terrible conditions. While many efforts have been made by the Member States to save lives at sea, in particular after more than 400 people

\footnotetext{
3 Council Decision of 26 April 2010 supplementing the Schengen Borders Code as regards the surveillance of the sea external borders in the context of operational cooperation coordinated by the European Agency for the Management of Operational Cooperation at the External Borders of the Member States of the European Union, OJ L 111/20, 4.5.2010.

${ }^{4}$ C-355/10, supra note 2, paras. 84 and 90.
} 
drowned near Lampedusa in October 2013, the situation is far from satisfactory. ${ }^{5}$ Unfortunately, the new Regulation will not avoid the continuous shipwrecks and losses of lives in the Mediterranean Sea. The aim of this paper is to determine to what extent Regulation 656/2014 has introduced a clear legal framework for the interception and rescue operations coordinated by Frontex while at the same time fully respecting fundamental rights and, in particular, the principle of non-refoulement. In this respect, it is relevant to consider that some of the individuals intercepted in the context of Frontex operations may be entitled to international protection within the meaning of the 1951 United Nations Convention relating to the Status of Refugees ('Refugee Convention').

The paper is organized in four sections. The first section of this paper will be devoted to analysing the broad concept of border surveillance adopted by the Regulation on the sea border operations coordinated by Frontex. In the following two sections, the paper will focus on examining to what extent the new rules applicable to the detection, interception of vessels, and search and rescue situations respect the obligations arising from the main international law treaties binding on the Member States. Finally, in the fourth section, the paper provides a detailed exam of the principle of non-refoulement in the context of Frontex operations. It is important to determine the content and scope of the principle of non-refoulement when interception of vessels takes place in the territorial seas and contiguous zone of the Member States. Furthermore, it is crucial to know whether the principle applies extraterritorially, in particular on the high seas and in the territorial waters of third states.

\section{A broad concept of border surveillance}

The scope of application of the Regulation is the same as that of the Decision: it regulates border surveillance operations carried out by the Member States at their external sea borders under the coordination of Frontex. The Regulation states the need to lay down specific rules with regard to border surveillance activities carried out by maritime, land and aerial units of the Member States at the sea border of other Member States or on the high seas in the context of operational cooperation coordinated by Frontex.

\footnotetext{
5 See Parliamentary Assembly of the Council of Europe, 'The "left-to-die boat": actions and reactions', Doc. 13532, 9 June 2014, and 'Lives lost in the Mediterranean Sea: who is responsible?', 29 March 2012.
} 
One of the most significant novelties included in the Regulation is that it clarifies the concept of border surveillance. In the Decision, the concept of border surveillance included the interception and rescue measures arising during a border surveillance operation, but it was not clear to what extent those measures fell under the concept of border surveillance as defined in the Schengen Borders Code. ${ }^{6}$ In the new Regulation border surveillance is not limited to the detection of attempts of irregular crossing and interception measures, but also includes arrangements intended to address situations such as search and rescue that may arise during surveillance operations at sea. $^{7}$ According to the preamble of the Regulation:

\footnotetext{
'border surveillance is not limited to the detection of attempts at unauthorised border crossings but equally extends to steps such as intercepting vessels suspected of trying to gain entry to the Union without submitting to border checks, as well as arrangements intended to address situations such as search and rescue that may arise during a border surveillance operation at sea and arrangements intended to bring such an operation to a successful conclusion'.
}

In the adoption of the new rules, the amendments to Regulation 2007/2004 needed to be taken into account. ${ }^{8}$ Since 2011 Frontex is also entrusted with assisting Member States in circumstances requiring increased technical assistance at the external borders, taking into account the fact that some situations involve humanitarian emergencies and rescue at sea. ${ }^{9}$ Although the Agency does not become a SAR body, during a sea operation it assists Member States who are obliged under international maritime law to provide assistance to persons in distress. ${ }^{10}$ In practice, it appears that most of Frontex operations end up becoming search and rescue operations. This has been recently underlined by the Commission in pointing out that 'although Frontex is neither a search and rescue body nor does it take up the functions of a Rescue Coordination Centre, it

\footnotetext{
${ }^{6}$ Proposal for a Regulation of the European Parliament and of the Council establishing rules for the surveillance of the external sea borders in the context of operational cooperation coordinated by the European Agency for the Management of Operational Cooperation at the External Borders of the Members States of the European Union, COM (2013) 197, 12.4.2013

${ }^{7}$ Recital 1 of Regulation $n^{\circ}$ 656/2014, supra note 1.

${ }^{8}$ Regulation of the European Parliament and of the Council of 25 October 2011 amending Council Regulation (EC) No. 2007/2004 establishing a European Agency for the Management of Operational Cooperation at the External Borders of the Member States of the European Union, OJ L 304, 1 (22 Nov. 2011).

${ }^{9}$ Regulation of the European Parliament and of the Council of 25 October 2011 amending Council Regulation (EC) No. 2007/2004 establishing a European Agency for the Management of Operational Cooperation at the External Borders of the Member States of the European Union, OJ L 304, 1 (22 Nov. 2011).

${ }^{10}$ Recital 4 of Regulation $n^{\circ}$ 656/2014, supra note 1.
} 
assists Member States to fulfil their obligations under international maritime law to render assistance to persons in distress'. ${ }^{11}$

The broad concept of border surveillance enshrined in the Regulation on sea border operations should be understood within the context of a long-standing debate over the extent to which the concept of border surveillance also subsumes SAR obligations. ${ }^{12}$ The Court of Justice examined the meaning of the concept of border surveillance in case C-355/10. The European Parliament contended that activities such as SAR and disembarkation did not fall within the concept of border surveillance. ${ }^{13}$ However, the Council argued that, although SAR activities cannot be considered surveillance in the narrow sense, in case such a situation were to occur during a Frontex maritime operation, "it would be indispensable to coordinate in advance how the search and rescue was conducted by various participating Member States'. ${ }^{14}$ In the Commission's view, 'in many instances, the surveillance operation will prompt the search and rescue situation, and it is not possible to draw a sharp distinction between those operations' ${ }^{15}$ Finally, the Court of Justice held that border surveillance 'entails political choices falling within the responsibilities of the European Union legislature, in that it requires the conflicting interests at issue to be weighed up on the basis of a number of assessments. Depending on the political choices on the basis of which those rules are adopted, the powers of the border guards may vary significantly'. ${ }^{16}$ Furthermore, the Court added that the power conferred on border guards by the contested Decision meant that 'fundamental rights of the persons concerned may be interfered with to such an extent that the involvement of the European Union legislature is required'. ${ }^{17}$

\section{Rules applicable to the detection and interception of vessels}

As regards interception, the regulation distinguishes between the detection and interception of vessels in the territorial sea, on the high seas and in the contiguous zone.

\footnotetext{
${ }^{11}$ European Commission, 'Frontex Joint Operation Triton' - concerted efforts to manage migration in the Central Mediterranean, 7 October 2014.

${ }^{12}$ S. Carrera and L. Den Hertog, 'Whose Mare? Rule of law challenges in the field of European border surveillance in the Mediterranean', CEPS Paper no 79, January 2015, p. 12.

${ }^{13} \mathrm{C}-355 / 10$, supra note 2, para. 50 .

${ }^{14}$ Ibídem, para 4.

${ }^{15}$ Ibídem, para 56.

${ }^{16}$ Ibídem, para 76.

${ }^{17}$ Ibídem, para 77.
} 
The Regulation contributes substantially to clarify the conditions under which these measures may be taken. Evidently, Frontex surveillance operations at sea are bound by the legal regime laid down in the UNCLOS as regards both territorial waters and the high seas.

In the territorial sea of the host Member State or of a neighboring participating State, 'where there are reasonable grounds to suspect', that a vessel is engaged in the smuggling of migrants by the sea, the Frontex operation may stop and search the vessels, its cargo and persons on board' ${ }^{18}$ When the migrants are intercepted in the territorial sea, they must be disembarked in the coastal Member States in accordance with the operational plan. Therefore, the law applicable in detection and interception activities in the territorial sea of the Member States is clearly laid down in the Regulation.

In the Commission proposal, the measures that may be adopted as regards the migrants intercepted in the contiguous zone were similar to the ones of the territorial sea. ${ }^{19}$ Therefore, in the final version of the Regulation, the relevant provisions have aligned to those of the UNCLOS. The authorization to board and intercept a vessel 'may only be given for measures that are necessary to prevent the infringement of relevant laws and regulations within that Member State's territory or territorial sea'. ${ }^{20}$

A far more complex issue is undoubtedly that of the detection and interception of vessels on the high seas. According to international treaty and customary law, in this zone, boats are only bound by their flag State. Hence, in the new Regulation, the interception of ships involved in the smuggling of migrants on the high seas is subject to the authorization of the flag State. ${ }^{21}$ The smuggling of migrants is not contemplated by Article 110 of the UNCLOS as a ground for the right to visit a foreign vessel. If the evidence found confirms that the vessel is engaged in transporting and trafficking with persons, Frontex participating units may seize the vessel, order the vessels not to enter the territorial sea, conduct the vessels or persons on board to a third country, to the host Member State or to a neighbouring participating Member State. However, many of the

\footnotetext{
${ }^{18}$ Article 6 of Regulation $n^{\circ} 656 / 2014$, supra note 1.

${ }^{19}$ See Meijers Committee, Standing committee of experts on international immigration, refugee and criminal law, Note on the Proposal for a Regulation establishing rules for the surveillance of the external sea borders in the context of operational cooperation coordinated by Frontex (COM(2013) 197 final), 23 May 2013. p. 4

${ }^{20}$ Article 8 of Regulation $n^{\circ} 656 / 2014$, supra note 1 .

${ }^{21}$ Article 7 of Regulation $n^{\circ} 656 / 2014$, supra note 1.
} 
vessels involved in the trafficking of illegal migrants or refugees and intercepted in the context of Frontex operations have no nationality. ${ }^{22}$ According to Article 110(1) (d), warships or other duly authorized vessels of any State may exercise the right of visit on this sort of vessels. Besides, the Regulation contemplates the possibility that a stateless vessel may be engaged in the smuggling of migrants. In these cases, the Frontex operation would have to inform the host Member State who may take any of the measures mentioned above. In conclusion, the new Regulation clarifies the conditions under which the interception on the high seas may take place and the jurisdictional basis on which action may be taken as regards stateless ships. ${ }^{23}$

\section{Rules applicable to the search and rescue situations}

Account should be taken of the fact that during the deployment of Frontex surveillance operations at sea a situation may occur where it will be necessary to render assistance to persons found in distress. For those purposes, the Regulation lays down rules applicable to the search and rescue (SAR) situations and, should the need arise, for disembarkation. The obligation to render assistance to persons in distress is very often the legal basis for the boarding of vessels in the high seas by Member States within the context of Frontex operations. ${ }^{24}$ However, the responsibility under the UNCLOS and customary law on search and rescue situations is a competence of the Member States that has not been transferred to the EU. Consequently, since the UNCLOS is binding on the EU as regards to matters transferred by the Member States to the EU, the obligations arising from this Convention are not incumbent on Frontex on the rescue at sea. ${ }^{25}$

While the rules included in the 2010 Decision were not binding, the Regulation now includes a set of legally-binding rules. ${ }^{26}$ It was precisely the binding character of rules on SAR included in the Commission's proposal that gave rise to fierce protests from the part of a group of States with Mediterranean Sea borders. Italy, Greece, Spain, Malta, France Cyprus contended that the regulation of search and rescue and disembarkation in an EU legislative instrument was unacceptable because these issues fell within the

\footnotetext{
${ }^{22}$ See articles 91 and 110 UNCLOS.

${ }^{23}$ COM (2013) 197 final.

${ }^{24}$ See Article 98 UNCLOS.

25 E. Papastavridis, 'Fortress Europe' and FRONTEX: Within or Without International Law?', Nordic Journal of International Law 79 (2010), p. 86.

${ }^{26}$ Although the guidelines included in the 2010 Decision were not binding, its inclusion in the operational plan prepared for each Frontex operation let the Court of Justice to consider that the rules were intended to produce binding legal effects (Case C-355/10, supra note, para. 84).
} 
exclusive competence of Member States to be exercised in the framework of international conventions. ${ }^{27}$ They intended to avoid that new obligations and responsibilities would arise from the Frontex Regulation on border surveillance when they carry out SAR activities. These Member States considered that these matters should be determined in the operational plans of each specific joint Frontex operation and not in the Regulation. Furthermore, since the 2011 amendments to the Frontex Regulation, the operational plan is clearly a binding legal document. ${ }^{28}$ This group of Member States finally withdrew their opposition to the adoption of the Regulation, once it was guaranteed that SAR and disembarkation rules were not applicable to national operations, such as the Mare Nostrum operation deployed by Italy in the Mediterranean Sea. Hence, Articles 9(2) and 10(1) of the Regulation state that the 'operational plan shall contain... at least' the listed provisions included. Even though the scope of application of the Regulation could lead to the deduction that SAR and disembarkation obligations are exclusively applicable to joint operations coordinated by Frontex, these provisions reassured the Member States on the fact that these requirements relate exclusively to Frontex operations. ${ }^{29}$

Concerning search and rescue situations, the content of the Regulation is similar to that of the Decision. ${ }^{30}$ Member States are obliged to render assistance to any vessel or person in distress at sea during a sea operation, in accordance with international treaties that establish the rules on search and rescue and respect for fundamental rights. Furthermore, the Regulation states that the participating units in Frontex surveillance operations shall render assistance regardless of the nationality or status of such person or the circumstances in which that person is found. The new Regulation includes criteria to determine when a ship is considered to be in a phase of uncertainty, alert and distress. When any of these situations arise, Frontex participating units have to transmit all available information to the Rescue Coordination Centre (RCC) responsible for the

\footnotetext{
27 "Any rules that depart from those in the international regime would be unacceptable, as we would effectively be creating an EU regime that runs in parallel with the international regime but which would be applied in Frontex-coordinated joint operations and insofar as no third countries are involved in the case" (Proposal for a Regulation of the European Parliament and of the Council establishing rules for the surveillance of the external sea borders in the context of operational cooperation coordinated by the European Agency for the Management of Operational Cooperation at the External Borders of the Members States of the European Union, doc. 14612/13, 10 October 2013)

${ }^{28}$ See Article 3a (j) of the 2011 Frontex Regulation, supra note 9.

${ }^{29}$ S. Carrera and L. Den Hertog, 'Whose Mare? Rule of law challenges in the field of European border surveillance in the Mediterranean', CEPS Paper $\mathrm{n}^{\circ}$ 79, January 2015, p. 12.

${ }^{30}$ Article 9 of Regulation $\mathrm{n}^{\circ}$ 656/2014, supra note 1.
} 
search and rescue area and have to follow the instructions provided by the Rescue Centre. A rather problematic question arises when the RCC of a third country responsible for a SAR area does not respond to the information transmitted by the Frontex operation. In those circumstances, the RCC of the host Member State should generally assume the coordination of the SAR situation. ${ }^{31}$ Since the SAR capacity in North African countries is very weak, in particular in Libya, it is essential that the European RCC are immediately contacted when boats in distress are identified in order to save lives. ${ }^{32}$

The Regulation includes also guidelines to be followed when the boat in question is considered to be in a situation of uncertainty but the persons on board refuse to accept assistance. In this case Frontex units not only have to inform the responsible RCC but also shall continue to fulfil a duty of care 'by taking any measure necessary for the safety of the persons concerned, while avoiding to take any action that might aggravate the situation'.

Finally, the Regulation clearly establishes what it is to be included in the operational plan on the modalities for the disembarkation of the persons intercepted or rescued, in accordance with international law and respect for fundamental rights. ${ }^{33}$ As regards interception in the territorial sea or in the contiguous zone, the disembarkation takes place in the coastal Member State. As regards interception on the high seas, the disembarkation may take place in the third country from which the ship departed. However, 'if that is not possible, disembarkation will take place in the host Member State'. 34

As regards disembarkation in the case of a rescue operation, the Regulation the Frontex coordinated operation has to cooperate with the responsible Rescue Coordination Centre to identify a place of safety and to ensure a rapid and effective disembarkation. ${ }^{35}$ The new Regulation takes into account that in case of search and rescue situations, the Frontex operating units would be acting under the coordination of the Rescue Coordination Centre. However, the Regulation lays down the possibility to

\footnotetext{
${ }^{31}$ Article 9 (2.i) of Regulation $n^{\circ}$ 656/2014, supra note 1.

${ }^{32}$ Parliamentary Assembly of the Council of Europe, 'The "left-to-die boat": actions and reactions', Doc. 13532, 9 June 2014, p. 14.

${ }^{33}$ Article 10 of Regulation $n^{\circ} 656 / 2014$, supra note 1.

${ }^{34}$ Article 10 (1.a) of Regulation $\mathrm{n}^{\mathbf{0}}$ 656/2014, supra note 1.

${ }^{35}$ Article 10 (1.c) of Regulation $n^{\circ} 656 / 2014$, supra note 1.
} 
disembark the rescued persons in the host Member State if the participating units are not released of their obligation to render assistance to the persons in distress as soon as possible.

\section{The Principle of Non-Refoulement in the context of Frontex Operations}

One of the most complex questions raised by Frontex operations is the application of the principle of non-refoulement. What is at stake is to what extent are Member States obliged not to return or reject persons in need of international protection to third countries. This discussion has dealt mainly on the treatment that must be granted to persons on board of the vessels intercepted on the high seas and in the territorial waters of third states. ${ }^{36}$ In order to determine whether the new Regulation provides a fully satisfactory response from the legal perspective, the content and scope of the principle of non-refoulement under Public International Law should be examined. In the context of Frontex operations, it is fundamental to know whether the principle applies extraterritorially, in particular on the high seas and in the territorial waters of third states.

\subsection{The principle of non-refoulement in international law}

The prohibition against transferring an individual to a country where he or she would face a real risk of being tortured or ill-treated is firmly anchored in international law. There is an express reference to the principle of non-refoulement in article 3 of the Convention against torture and other cruel, inhuman or degrading Treatment (CAT) and in article 33 of the 1951 Refugees Convention. ${ }^{37}$ Even though the International Covenant on Civil and Political Rights ('Convenant') and the European Convention on

\footnotetext{
${ }^{36}$ See A. Fischer-Lescano, T. Löhr and T. Tohidipur, 'Border Controls at Sea: Requirements under International Human Rights and Refugee Law', 21 International Journal of Refugee Law (2009), 256296; S. Klepp, 'A contested Asylum System: The European Union between Refugee Protection and Border Control in the Mediterranean Sea', 12 European Journal of Migration and Law (2010), 1-21; E. Papastavridis, supra note 25.

${ }^{37}$ Article 3 of the Convention against Torture states that "no State Party shall expel, return ("refouler"), or extradite a person to another State where there are substantial grounds for believing that he would be in danger of being subjected to torture". Article 33 of the Refugee Convention says that "no Contracting Party shall expel or return ("refouler") a refugee in any manner whatsoever to the frontiers of territories where his life or freedom would be threatened on account of his race, nationality, membership of a particular social group or political opinion".
} 
Human Rights ('ECHR) do not explicitly mention the protection against refoulement, they have been interpreted as including such a principle. ${ }^{38}$

Article 3 of the CAT would be violated regardless of whether the person returned or disembarked in a third country was actually tortured in the country of destination. The absolute character of the prohibition from removal when there is a reasonable risk of torture does not allow for any exception or derogation. ${ }^{39}$ As Frederic L. Kirgis says, this provision 'looks to what would be expected rather than to what actually happened after the individual has been turned over'. ${ }^{40}$ In order to determine whether such 'substantial grounds' exist, Article 3 of the Torture Convention requires the competent authorities 'to take into account all relevant considerations including, where applicable, the existence in the State concerned of a consistent pattern of gross, flagrant or mass violations of human rights'. ${ }^{41}$ The CAT Committee has considered that 'the risk of torture must be assessed on grounds that go beyond mere theory of suspicion. However, the risk does not have to meet the test of being highly probable'. ${ }^{42}$ Therefore, in order to determine if there is a risk of torture or ill-treatment in the country to which the illegal migrants or refugees are disembarked, attention should be paid to the prevailing political conditions in the receiving State and the personal circumstances of the individual that makes him/her vulnerable to suffer torture or other forms of illtreatment. $^{43}$

Although the prohibition of disembarking or conducting an individual to a country where there are substantial grounds for believing that he or she would be in danger of suffering torture, cruel, inhuman or degrading treatment is not explicitly laid down in Article 7 of the Covenant, the Human Rights Committee considered that it 'would run counter to its object and purpose'. ${ }^{44}$ Consequently, the Committee determined that,

\footnotetext{
${ }^{38}$ ECHR, Soering v. The United Kingdom, judgement of 7 July 1989, Series A No. 161, para. 88.

${ }^{39}$ The Committee against Torture considers that "another State" in article 3 refers not only to the State to which the individual concerned is being expelled, returned or extradited, but also to any State to which the author may subsequently be expelled, returned or extradited (General Comment No. 01: Implementation of article 3 of the Convention in the context of article 22: 21/11/97. A/53/44, annex IX, CAT General Comment No. 01. (General Comments).

${ }^{40}$ Frederic L. Kirgis, Alleged CIA Kidnapping of Muslim Cleric in Italy, ASIL, July 7, 2005, available at (http://www.asil.org/insights/2005/07insights050707.html. (last visited 20 February 2014).

${ }^{41}$ Art. 3(2) of the Convention against torture.

${ }^{42}$ General Comment No. 1 on article 3, para. 6.

${ }^{43} \mathrm{See}$ Interim report of the Special Rapporteur of the Commission of Human Rights on the question of torture, supra note 40, para. 31.

${ }^{44}$ A. R. J. v. Australia, Communication No. 692/1996, U.N. Doc. CCPR/C/60/D/692/1996 (1997), para. 3.3.
} 
according to Article 7 of the Covenant, States parties to the Covenant 'must not expose individuals to the danger of torture or cruel, inhuman or degrading treatment or punishment upon return to another country by way of their extradition, expulsion or refoulement'. ${ }^{45}$ Also, the Human Rights Committee held that the protection against refoulement is included in the Article 2 obligation 'to respect and to ensure to all individuals within its territory and subject to its jurisdiction the rights recognized by the Covenant'. ${ }^{46}$

On the other hand, it is very important to take into account the answers provided to this issue by the European Court of Human Rights, as the participating units in Frontex operations belong to States that are contracting parties of the ECHR. Even though the Convention does not specifically lay down an explicit prohibition against refoulement, the European Court of Human Rights considered this obligation to be inherent to Article 3 of the ECHR. ${ }^{47}$ The Court has stated that a Contracting State engages its responsibility under the Convention when it expels or returns a person to a country, where there are substantial grounds to believe that the person in question would face 'a real risk' of being subjected to treatment contrary to Article 3 of the European Convention in the receiving country. ${ }^{48}$ In order to determine whether a violation of the prohibition against refoulement occurred or not, an assessment of conditions in the country where the individuals where disembarked or forced to enter should be made against the standards of Article 3 of the ECHR. ${ }^{49}$

Article 33(1) of the Refugee Convention prohibits the expulsion or refoulement of any refugee to a country "where his life or freedom would be threatened on account of

\footnotetext{
${ }^{45}$ Human Rights Committee, General Comment 20, article 7, U.N. Doc. A/47/40 (1992), para.9, contained in Compilation of General Comments and General Recommendations Adopted by Human Rights Treaty Bodies, U.N. Doc. HRI/GEN/1/Rev.7. (2004).

${ }^{46}$ Human Rights Committee, General Comment 31, Nature of the General Legal Obligation on States Parties to the Covenant, U.N. Doc. CCPR/C/21/Rev.1/Add.13 (2004). The Human Rights Committee said that the obligations of the States to "respect and ensure the Covenant rights for all persons in their territory and all persons under their control entails an obligation not to extradite, deport, expel or otherwise remove a person from their territory, where there are substantial grounds for believing that there is a real risk or irreparable harm, such as that contemplated by articles 6 and 7 of the Covenant, either in the country to which removal is to be effected or in any other country to which the person may subsequently be removed" (Human Rights Committee, General Comment 31, para. 12).

${ }^{47}$ ECHR, Soering v. The United Kingdom, judgement of 7 July 1989, Series A No. 161, para. 88.

${ }^{48}$ ECHR, Chahal v. United Kingdom, supra note 51, para. 80; ECHR, Soering, supra note 64, paras. 88 and 113 .

${ }^{49}$ Soering, supra note 47, para. 91). In the Mamatkulov case, the ECHR stated that the existence of the risk of being tortured or submitted to inhuman or ill-treatment must be assessed "primarily with reference to those facts which were known or ought to have been known to the Contracting State at the time of the expulsion" (Mamatkulov and Askarov v. Turkey, judgment of 4 February, 2005, para. 69).
} 
his race, religion, nationality, membership in a particular social group or political opinion'. In contrast to the international human rights treaties analysed previously, the Refugee Convention does not refer to the risk of suffering torture or other inhuman or degrading treatment, but rather to the danger to the life or liberty of a person for any of the above-mentioned reasons. Whereas in the CAT, the Covenant and the ECHR the protection against refoulement is considered in an absolute way and without any possibility of including exceptions, the Refugee Convention foresees the possibility of establishing limitations. In Article 33(2) it is foreseen that the prohibition of refoulement is not extended to those cases in which the refugee is a danger to the security of the country in which he is, or who has been convicted of a particularly serious crime.

Finally, given that a great number of international human rights treaties include the prohibition against refoulement, the conclusion could be drawn that this norm has acquired consuetudinary value. ${ }^{50}$ It could also be held that the principle of nonrefoulement belongs to the category of peremptory norms. ${ }^{51}$ Therefore, Member States participating in a Frontex surveillance operation at sea could violate this rule of general international law, regardless of whether they are contracting parties to the agreements that include the obligation of non-refoulement or not.

\subsection{The extraterritorial effect of the norm}

The main international human rights conventions, such as the Convenant and the ECHR do not expressly foresee their application to the extraterritorial activities of the States parties. It is crucial to determine whether or not these treaties apply to Frontex maritime interception operations carried out on the high seas and in the territorial waters of the third States.

\footnotetext{
${ }^{50}$ The UN Sub-Commission on the Promotion and Protection of Human Rights has confirmed that customary international law prohibits the involuntary transfer of a person who "faces a real risk of being subjected to torture, cruel, inhuman or degrading treatment or extrajudicial killing..." (Resolution on the Transfer of Persons, UN Doc. E/CN/.4/Sub.2/2005/1.12, August 4, 2005). Guy S. Goodwin-Gill says that the fact that States have not objected the consideration of the principle of non-refoulement as a rule of international customary law made regularly by international organizations, like the UN General Assembly and UNHCR confirmed its consuetudinary value (Guy S. Goodwin-Gill, The Refugee in international law (1996).

${ }^{51}$ See J. Allain, 'The jus cogens Nature of non-refoulement', 13 International Journal of Refugee Law 13 (2002); J. Santos Vara, 'Extraordinary renditions: the interstate transfer of terrorist suspects without human rights limits', in M. Glennon; S. Sur (Ed.):Terrorism and International Law, Hague Academy of International Law, Ed. Martinus Nijhoff Publishers, Leiden, 2008, pp. 551-583
} 
Although the Human Rights Committee has not pronounced itself expressly on the extraterritorial application of the Covenant, on the basis of the decisions of the Committee on Human Rights the conclusion can be drawn that the Covenant is applicable to the maritime interception of vessels engaged in the smuggling of migrants by sea. The Committee held in López Burgos v. Uruguay that the obligation that Article 2(1) of the Covenant imposes on the State Parties to respect and to ensure the rights 'to all individuals within its territory and subject to its jurisdiction' does not mean that the State Parties cannot be held accountable for violations of human rights that their agents commit in the territory of another State. ${ }^{52}$ Therefore, the Committee considered that it would be unconscionable to so interpret the responsibility under article 2 of the Covenant as to permit a State party to perpetrate violations of the Covenant on the territory of another State, which violations it could not perpetrate on its own territory'. ${ }^{53}$ Furthermore, the Human Rights Committee declared that the concept of jurisdiction means that 'a State Party must respect and ensure the rights laid down in the Covenant to anyone within the power or effective control of that State Party, even if not situated within the territory of the State Party', regardless of the nationality of the victim and of the circumstances in which such 'power or effective control' had been achieved. ${ }^{54}$ It could be affirmed that this understanding of the concept of jurisdiction has been assumed by the International Court of Justice in its Advisory Opinion on Legal Consequences on the Construction of a Wall in the Occupied Palestinian Territory where it considered 'that the (Covenant) is applicable in respect to acts done by a State in the exercise of its jurisdiction outside its own territory, 55 .

More recently, the UN High Commissioner for Refugees (UNHCR) held that

'an interpretation which would restrict the scope of application of Article 33(1) of the 1951

Convention to conduct within the territory of a State party to the 1951 Convention and/or its 1967

Protocol would not only be contrary to the terms of the provision as well as the object and purpose of the treaty under interpretation, but it would also be inconsistent with relevant rules of international human rights law. It is UNHCR's position, therefore, that a State is bound by its obligation under

\footnotetext{
${ }^{52}$ López Burgos v. Uruguay, supra note 20.

${ }^{53}$ Id., para. 12.3 .

${ }^{54}$ Human Rights Committee, General Comment No. 31, para.10.

${ }^{55}$ Legal Consequences on the Construction of a Wall in the Occupied Palestinian Territory, ICJ Advisory Opinion, 9 July 2004.
} 
Article 33(1) of the 1951 Convention not to return refugees to a risk of persecution wherever it exercises effective jurisdiction, ${ }^{56}$

In the same line, the European Court of Human Rights has consistently defended the extraterritorial application of the ECHR. ${ }^{57}$ In the case of Hirsi Jamaa and Others $v$. Italy, the Court dealt with an application made by eleven Somali nationals and thirteen Eritrean nationals, who were intercepted by Italian ships on the high seas and forced to return to Libya. ${ }^{58}$ On jurisdiction, the Court held that "whenever the State through its agents operating outside its territory exercises control and authority over an individual, and thus jurisdiction, the State is under an obligation under Article 1 to secure to that individual the rights and freedoms' under the Convention. ${ }^{59}$ The special nature of the maritime environment cannot justify an area outside the law where individuals are not covered by any legal system capable of affording them enjoyment of the rights and guarantees protected by the Convention. ${ }^{60}$

These arguments seem to confirm that the non-refoulement obligation applies not only to expulsions or removals from the territory of Member States, but also to the treatment of persons intercepted onboard of vessels on the high seas and in the territorial waters of the States of departure. Independently of the fact that persons are illegal migrants or refugees, the participating units within the context of a Frontex border surveillance operation are obliged to respect the principle of non-refoulement. Therefore, if the Member States involved in a Frontex joint operation disembark or conduct persons to a country where they face a risk of being tortured or suffered an analogous treatment, they will incur in international responsibility for the violation of the human rights treaties mentioned above. ${ }^{61}$

\subsection{The principle of Non-Refoulement in the New Regulation}

\footnotetext{
${ }^{56}$ UNHCR, Advisory Opinion on the Extraterritorial Application of Non-Refoulement Obligations under the 1951 Convention relating to the Status of Refugees and its 1967 Protocol, 21.01.2007.

57 The European Court of Human Rights has maintained similar views considering that "le terme juridiction ne se limite pas au territoire des Hautes parties contractantes; leur responsabilité peut entrer en jeu à raison d'actes émanant de leurs organes et déployant leurs effets en dehors dudit territoire" (ECHR, Drodz et Janousek v. France and Spain, judgment of 26 juin 1992, Seris A, no 240, para. 91). See ECHR, Issa v. Turkey, judgment of 6 November 2004, paras. 71-74; ECHR, Loizidou v. Turkey, (1995) Series A, No. 310, para.52).

${ }^{58}$ European Court of Human Rights, Grand Chamber, Hirsi Jamaa and Others v. Italy, n. 27765/09, of 23 February 2012.

${ }^{59}$ Ibidem, para 74 .

${ }^{60}$ Ibidem, para 178.

${ }^{61}$ See E. Papastavridis, supra note 25, p. 105.
} 
The principle of non-refoulement enshrined in Article 19 (2) of the Charter of Fundamental Rights of the EU is developed in the new Regulation in the context of border surveillance activities carried out by the Member States in the context of the Frontex operations. The Regulation includes important improvements with a view to ensuring that disembarkation of intercepted or rescued persons complies with international human rights obligations. Article 4 of the Regulation states that

\footnotetext{
'No person shall, (...), be disembarked in, forced to enter, conducted to or otherwise handed over to the authorities of a country where, inter alia, there is a serious risk that he or she would be subjected to the death penalty, torture, persecution or other inhuman or degrading treatment or punishment, or where his or her life or freedom would be threatened on account of his or her race, religion, nationality, sexual orientation, membership of a particular social group or political opinion, or from which there is a serious risk of an expulsion, removal or extradition to another country in contravention of the principle of nonrefoulement'.
}

As can be perceived, the Regulation introduces a clear definition of the principle of nonrefoulement. In contrast, the 2010 Decision included a general reference to the obligation of non-refoulement without detailing its content. The new Regulation introduces a series of guarantees with the objective of implementing the decision taken by the Grand Chamber of the European Court of Human Rights in Hirsi v. Italy. The forced return to Libya implied that the intercepted persons were not identified nor informed of their fate nor of the procedures that they could avail of to challenge the decision to hand them over to the Libyan authorities. In this judgment, the Court held that Italy infringed Article 3 of the Convention by exposing the persons transferred to Libya to the risk of being subject to ill-treatment. The Court also found a breach by Italy of Article 13 on the right to an effective remedy in conjunction with Article 3 and of Article 13 of the Convention taken in conjunction with Article 4 of Protocol No. 4 to the Convention.

Article 4 of the Regulation lays down clear rules on the disembarkation of rescued or intercepted persons at sea. When considering the possibility of disembarking migrants in a third country, the host Member State of the operation, in coordination with participating Member States and Frontex, 'shall take into account the general situation in that third country'. ${ }^{62}$ The new rules oblige to take account of the human rights situation in the third country, to identify the intercepted or rescued persons, to inform the persons on board of their destination and to give them the opportunity to express reasons for believing that the disembarkation in the proposed country would violate the

\footnotetext{
${ }^{62}$ Article 4(2) of Regulation $n^{\circ}$ 656/2014, supra note 1.
} 
principle of non-refoulement. ${ }^{63}$ For those purposes, the operational plan must also provide 'where necessary' for the availability of shore-based medical staff, interpreters, legal advisers and other relevant experts. The determination on whether intercepted persons on the high seas can be returned to third countries has to be carried out upon the assessment by the participating units in contact with the RCC. In so doing, the aim is to put a clear end to the push-back practice developed in the past by certain States, and especially by Italy, though which migrants were forced to enter or to return to unsafe countries.

In order to determine whether or not a third country is safe or unsafe, the new Regulation refers to information coming from a broad range of sources, including other Member States, EU bodies and agencies, and relevant international organizations. The Agency and the Member State will also have to take into account the existence of agreements and projects on migration and asylum between the EU, its Member States and third countries when making such assessment. The tendency to externalize migration controls and asylum policy to third countries does not contribute to the prevention of human rights violations. ${ }^{64}$ Therefore, the strong role provided to these agreements and projects concluded with third countries in the development of the operational plan cannot be understood.

Since the Regulation applies not only to the interception and rescue of migrants in the territorial sea and contiguous zone, but also to similar activities carried out on the high seas, the principle of non-refoulement clearly applies to Frontex border surveillance operations carried out extraterritorially. This a welcome development because the EU asylum legislation only applies to applications made in the territorial waters of the Member States. ${ }^{65}$ However, as the Meijers Committee pointed out when examining the Commission proposal, the Regulation does fully incorporate the judgment in Hirsi. ${ }^{66}$ The ECHR considered that the migrants should have had access to a remedy before a

\footnotetext{
${ }^{63}$ Article 4 (3) of Regulation $\mathrm{n}^{\mathrm{o}}$ 656/2014, supra note 1.

${ }^{64}$ See A. Baldaccini, The External Dimension of the EU's Asylum and Immigration Policies: Old Concerns and New Approaches, in A. Baldaccini, E. Guild, H. Toner (Eds.), Whose Freedom, Security and Justice? EU Immigration and Asylum Law and Policy, 277 (2007).

${ }^{65}$ See S. Peers, 'New EU rules on maritime surveillance: will they stop the deaths and pushs-backs in the Mediterranean? Statewatch, 2014.

${ }^{66}$ Meijers Committee, Standing committee of experts on international immigration, refugee and criminal law, Note on the Proposal for a Regulation establishing rules for the surveillance of the external sea borders in the context of operational cooperation coordinated by Frontex (COM(2013) 197 final), 23 May 2013.
} 
competent authority before the removal was enforced, including interpreters, legal advisers and a suspension of the return in case an appeal is lodged. ${ }^{67}$ Indeed, the Regulation does not guarantee the access to an effective remedy, as laid down in Article 47 of the Charter of Fundamental Rights, before the illegal migrants or refugees are disembarked or forced to enter a third country.

Nevertheless, the Regulation does not lay down a legal framework in which Frontex operations in the territorial sea of third countries must be carried out. Regard should be paid to the fact that in the context of Operations HERA II and III in 2008, the bilateral agreements concluded between Spain and Mauritania and Spain and Senegal furnished the legal basis for such operations. The Regulation does not apply in a similar situation and there are no guarantees that the obligation of non-refoulement applies extraterritorially in the operations carried out in the territorial waters of third countries. ${ }^{68}$ However, the European Court of Human Rights affirmed in Hirsi v. Italy that the contracting State's responsibility is not avoided by relying on its obligations arising out of bilateral agreements with third countries. ${ }^{69}$ Consequently, as it was pointed out above, the States remain subject to their international human rights obligations when they carry out extraterritorial activities in the territorial waters of third states.

As a result of the demands of the European Parliament, Frontex will have to prepare annual reports on the practical application of the Regulation, including a description of the procedures put in place during sea operations and 'detailed information on the application on compliance with fundamental rights and the impact of those rights, and any incidents which may have taken place'. ${ }^{70}$ These reports will allow to control whether Frontex and the Member States participating in joint operations respecting the obligations arising from the main international human rights instruments.

The question of whether the prohibition to disembark or to hand over the intercepted persons to a third state, in violation of the principle of non-refoulement, includes certain

\footnotetext{
${ }^{67}$ See para. 202 and 205 (Hirsi Jamaa and Others v. Italy, supra note 58).

${ }^{68}$ According to Carrera and Den Hertog "since Article 14(1) of the 2011 amended Frontex Regulation and Recital 5 of the Regulation on Frontex sea border surveillance operations now clearly stipulate the respect for Union law even if cooperation takes place in third state territorial waters, these kinds of practices will now trigger the responsibility of Frontex for possible incidents and human rights violations" (supra note 12, pp. 11-12).

${ }^{69}$ Para. 129 (Hirsi Jamaa and Others v. Italy, supra note 58).

${ }^{70}$ Article 13 (2) of Regulation $n^{\circ}$ 656/2014, supra note 1.
} 
Member States or not should be raised. Account must be taken of the fact that Greece has been as an unsafe State both by the European Court of Human Rights and by the European Court of Justice. ${ }^{71}$ In those cases, Frontex participating units can face the difficult task of opting between disembarking the intercepted persons in the host State or participating Member State or respecting the obligation of non-refoulement. Since Article 4 (1) of the Regulation refers to principle in general terms, it should be understood as including any EU Member State. ${ }^{72}$

As it was pointed out in the introduction of this paper, Frontex has been severely criticised from its early days for not paying sufficient regard to human rights in the context of its border surveillance operations. ${ }^{73}$ These critics were confirmed by the absence of any mention to the principle of non-refoulement in the 2004 Frontex Regulation. ${ }^{74}$ Regulation 1168/2011, which modified the 2004 Frontex Regulation, constantly states that the Agency is fully committed to respecting fundamental human rights both when it is acting independently and when it is in cooperation with third countries and international organizations. ${ }^{75}$ While the situation remains far from satisfactory, Frontex has undertaken a number of initiatives with a view to integrating fundamental human rights in its activities, such as the Frontex Fundamental Rights Strategy, the Frontex Consultative Forum on human rights and the appointment of a Fundamental Rights Officer. $^{76}$

\section{Conclusions}

The new Regulation establishes a legal framework to regulate the Frontex sea border surveillance operations that deals not only with border surveillance strictly speaking, but also SAR and disembarkation of persons carried out within the context of Frontex

\footnotetext{
${ }^{71}$ See ECHR, M.S.S. v. Belgium and Greece, Application $\mathrm{n}^{\mathbf{0}}$ 30696/09, judgment of 21 January 2011; Judgment of 21 December 2011, N.S. and others, C-411/10 and C-493/10.

${ }^{72}$ S. Peers, supra note 65.

${ }^{73}$ Parliamentary Assembly of the Council of Europe, Frontex: human rights responsibilities, Doc. 13161 8 April 2013.

${ }_{74}$ Council Regulation $n^{\mathbf{0}} 2007 / 2004$ of 26 October 2004 establishing a European Agency for the Management of Operational Cooperation at the External Borders of the Member States of the European Union, OJ L 349, 1 (25 Nov 2004).

${ }^{75}$ Regulation of the European Parliament and of the Council of 25 October 2011 amending Council Regulation (EC) No. 2007/2004 establishing a European Agency for the Management of Operational Cooperation at the External Borders of the Member States of the European Union, OJ L 304, 1 (22 Nov. 2011).

${ }^{76}$ See J. Santos Vara, 'The External Activities of AFSJ Agencies: The Weakness of Democratic and Judicial Controls' 20 (2015) European Foreign Affairs Review, pp. 118-136; A. Spengeman, 'Upholding the legitimacy of Frontex: European Parliamentary Oversight", European Security Review, Mars 2013.
} 
sea border operations. The broad concept of border surveillance adopted by the Regulation is better suited to the challenges constantly faced by Frontex operations compared to that included in the 2010 Decision, annulled by the Court of Justice in 2012. In the practice, it appears that most of Frontex border surveillance activities at sea end up becoming search and rescue operations. Therefore, the Regulation on maritime operations coordinated by Frontex must be praised for clarifying the rules applicable to all aspects of operations at sea, including interception, SAR and disembarkation.

With regard to the detection and interception of vessels, the Regulation distinguishes between the measures that may be taken in the territorial sea, on the high seas and in the contiguous zone. The Regulation substantially contributes to clarifying the conditions under which these measures may be taken. Obviously, Frontex surveillance operations at sea are bound by the legal framework laid down in the UNCLOS with respect to the territorial waters and the high seas.

While the rules included in the 2010 Decision on SAR situations were not binding, the Regulation includes a set of binding rules. It was precisely this legally binding character that caused the fierce opposition from a group of States with Mediterranean Sea borders. It is indeed rather paradoxical that at the same time as Italy was developing the Mare Nostrum operation - in the framework of which thousands of persons at sea have been rescued - it was also the biggest opponent to the imposition of new obligations and responsibilities on SAR under EU law.

The new Regulation clearly shows that Frontex surveillance sea operations are subject to international obligations stemming from the main human rights instruments and, in particular, to the principle of non-refoulement. In determining whether a given person can be disembarked or returned to a third country, the new rules oblige to take into account the human rights situation in the third country, to identify the intercepted or rescued persons, to inform the persons on board of their destination and to give them the opportunity to express reasons for believing that the disembarkation in the proposed country would violate the principle of non-refoulement. Since the Regulation applies not only to the interception and rescue of migrants in the territorial sea and contiguous zone, but also to similar activities carried out on the high seas, the principle of nonrefoulement clearly applies to the Frontex border surveillance operations carried out extraterritorially. Concerning extraterritorial application of the obligation of non- 
refoulement to the interception operations of migrants in the territorial seas of third countries, the Regulation does not apply. For that reason, in view of avoiding possible violations of human rights obligations of the Member States and, in particular, of the principle of non-refoulement, it is necessary to underline that, despite the Regulation does not apply to the territorial waters of third countries, Member States remain subject to their international human rights obligations when they are involved in border surveillance activities extraterritorially. 